\title{
Complete plastome sequencing of both living species of Circaeasteraceae (Ranunculales) reveals unusual rearrangements and the loss of the $n d h$ gene family
}

Yanxia Sun ${ }^{1}$, Michael J. Moore ${ }^{2}$, Nan Lin ${ }^{1,3}$, Kole F. Adelalu ${ }^{1,3}$, Aiping Meng ${ }^{1}$, Shuguang Jian ${ }^{4}$, Linsen Yang ${ }^{5}$, Jianqiang $\mathrm{Li}^{1 *}$ and Hengchang Wang ${ }^{1 *}$

\begin{abstract}
Background: Among the 13 families of early-diverging eudicots, only Circaeasteraceae (Ranunculales), which consists of the two monotypic genera Circaeaster and Kingdonia, lacks a published complete plastome sequence. In addition, the phylogenetic position of Circaeasteraceae as sister to Lardizabalaceae has only been weakly or moderately supported in previous studies using smaller data sets. Moreover, previous plastome studies have documented a number of novel structural rearrangements among early-divergent eudicots. Hence it is important to sequence plastomes from Circaeasteraceae to better understand plastome evolution in early-diverging eudicots and to further investigate the phylogenetic position of Circaeasteraceae.
\end{abstract}

Results: Using an Illumina HiSeq 2000, complete plastomes were sequenced from both living members of Circaeasteraceae: Circaeaster agrestis and Kingdonia uniflora. Plastome structure and gene content were compared between these two plastomes, and with those of other early-diverging eudicot plastomes. Phylogenetic analysis of a 79-gene, 99-taxon data set including exemplars of all families of early-diverging eudicots was conducted to resolve the phylogenetic position of Circaeasteraceae.

Both plastomes possess the typical quadripartite structure of land plant plastomes. However, a large $\sim 49 \mathrm{~kb}$ inversion and a small $\sim 3.5 \mathrm{~kb}$ inversion were found in the large single-copy regions of both plastomes, while Circaeaster possesses a number of other rearrangements, particularly in the Inverted Repeat. In addition, infA was found to be a pseudogene and $a c c D$ was found to be absent within Circaeaster, whereas all ndh genes, except for $n d h E$ and $n d h J$, were found to be either pseudogenized ( $\psi_{n d h A}, \psi_{n d h}, \psi_{n d h D}, \psi_{n} d h H$ and $\psi_{n d h K}$ ) or absent ( $n d h C, n d h F, n d h l$ and $n d h G$ ) in Kingdonia. Circaeasteraceae was strongly supported as sister to Lardizabalaceae in phylogenetic analyses.

Conclusion: The first plastome sequencing of Circaeasteraceae resulted in the discovery of several unusual rearrangements and the loss of ndh genes, and confirms the sister relationship between Circaeasteraceae and Lardizabalaceae. This research provides new insight to characterize plastome structural evolution in early-diverging eudicots and to better understand relationships within Ranunculales.

Keywords: Early-diverging eudicots, Circaeasteraceae, Plastome, Rearrangements, Gene loss, Phylogenetic analyses

\footnotetext{
* Correspondence: lijq@wbgcas.cn; hcwang@wbgcas.cn

'Key Laboratory of Plant Germplasm Enhancement and Specialty Agriculture,

Wuhan Botanical Garden, Chinese Academy of Sciences, Wuhan, Hubei, China

Full list of author information is available at the end of the article
} 


\section{Background}

The early-diverging eudicot family Circaeasteraceae (Ranunculales) sensu APG IV [1] contains only the two monotypic genera Circaeaster Maxim. and Kingdonia Balf.f. \& W.W. Smith, which were historically treated as separate families (Circaeasteraceae and Kingdoniaceae) (e.g. [2-6]). Kingdonia has also been placed in Ranunculaceae in the past (e.g. [7-10]). Circaeaster agrestis Maxim. can be found in China and the Himalayas, whereas Kingdonia uniflora Balf.f. \& W.W. Smith is endemic to China. Fossil fruits somewhat similar to those of Circaeaster have been reported from the mid-Albian of Virginia, USA [11, 12], while no fossil record is known for Kingdonia. Both species are herbs growing at high elevations, and possess the same distinctive dichotomous venation, which is very rare among angiosperms.

The Ranunculales sensu APG IV [1] form a wellsupported clade comprised of seven families: Berberidaceae, Circaeasteraceae, Eupteleaceae, Lardizabalaceae, Menispermaceae, Papaveraceae and Ranunculaceae. To date, complete plastomes have been sequenced for representatives from all of these families except Circaeasteraceae [13-24]. These and plastomes from other eudicot families have helped to successfully resolve phylogenetic relationships among early-diverging eudicots, including among most families of Ranunculales (e.g.[17-19, 23, 24]). This is highly promising given that the relationships among many of these families had been poorly to moderately resolved in previous studies utilizing only a few genes (e.g. [25-38]). In previous phylogenetic studies of Ranunculales based on only a few genes, Circaeasteraceae has been resolved as sister to Lardizabalaceae, but only with weak or moderate support [25, 26, 29, 32, 36, 38, 39].

Over the past decade, knowledge of the organization and evolution of angiosperm plastomes has rapidly expanded [40, 41]. Plastomes of most flowering plants possess a typical quadripartite structure with two Inverted Repeat regions $\left(\mathrm{IR}_{\mathrm{A}}\right.$ and $\left.\mathrm{IR}_{\mathrm{B}}\right)$ separating the Small and Large Single-Copy regions (SSC and LSC) [42]. Nevertheless, deviations from this canonical structure have been found with increasing frequency as the pace of plastome sequencing has exploded in recent years. For example, the length of the IR region has been found to vary significantly in some plant groups (e.g. [43-45]), and Sun et al. [23] documented six major "IR types" among 18 earlydiverging eudicot plastomes, representing 12 of the 13 early-diverging eudicot families. Reconstruction of the ancestral IR gene content suggests that 18 genes were likely present in the IR region of the ancestor of eudicots [23], although representatives from Circaeasteraceae were absent from this study. Likewise, large inversions have been detected throughout the plastome in an increasing number of taxa (e.g. [46-50]). However, no obvious large inversions or rearrangements have been detected from early-diverging eudicot plastomes. Finally, gene loss (including pseudogenization) has also been found to be widespread among angiosperm plastomes, especially in species whose plastomes are highly rearranged [51].

To characterize plastome structural evolution in earlydiverging eudicots and to better understand relationships within Ranunculales, we sequenced the complete plastomes of both extant species of Circaeasteraceae and included these two plastomes in a larger phylogenetic analysis including representatives of all major lineages of angiosperms. Consistent with previous work, we find that these complete plastome sequences improve support for phylogenetic relationships among Ranunculales, including the position of Circaeasteraceae. Moreover, we report several significant plastome structural changes, including a large inversion and several gene loss events.

\section{Results}

\section{Plastome assemblies}

Illumina paired-end sequencing produced 474,002 and 1,092,236 raw reads for Circaeaster and Kingdonia, respectively. The mean coverage of the plastome was $392.3 \times$ for Circaeaster, and 926.4× for Kingdonia. For both Circaeaster and Kingdonia, assembly yielded a single scaffold comprising the entire plastome sequence. Junction regions between the IR and Single-Copy regions were confirmed by PCR and Sanger sequencing (C8-C11 and K5-K8 in Additional file 1). Assembly statistics are presented in Table 1.

Table 1 Comparison of the plastid genomes of Circaeaster agrestis and Kingdonia uniflora

\begin{tabular}{|c|c|c|}
\hline & Circaeaster agrestis & Kingdonia uniflora \\
\hline Total plastome length (bp) & 151,033 & 147,378 \\
\hline IR length (bp) & 28,023 & 30,916 \\
\hline SSC length (bp) & 16,857 & 4857 \\
\hline LSC length (bp) & 78,130 & 80,689 \\
\hline Absent genes & $a c c D$ & $n d h C, n d h F, n d h l, n d h G$ \\
\hline Pseudogenes & $\psi_{\text {infA }}$ & $\begin{array}{l}\psi_{n d h A}, \psi_{n d h B}, \psi_{n d h D}, \\
\psi_{n d h H}, \psi_{n d h K}\end{array}$ \\
\hline Overall G/C content (\%) & 38.2 & 37.8 \\
\hline $\begin{array}{l}\text { Average depth of } \\
\text { coverage }\end{array}$ & $392.3 x$ & $926.4 x$ \\
\hline Number of plastid reads & 474,002 & $1,092,236$ \\
\hline Read length (bp) & 125 & 125 \\
\hline Genes with one intron & $\begin{array}{l}\operatorname{trnK} K-U U U, \operatorname{trnG}-U C C, \\
\operatorname{trn} L-U A A, \operatorname{trn} V-U A C, \\
\operatorname{trn}-G A U, \operatorname{trn} A-U G C, \\
\text { petB, petD, atpF, } \\
\text { ndhA, ndhB, rp/16, } \\
\text { rpoC1, rps16 }\end{array}$ & $\begin{array}{l}\operatorname{trnK}-U U U, \operatorname{trn} G-U C C, \\
\operatorname{trn} L-U A A, \operatorname{trn} V-U A C, \\
\operatorname{trn} l-G A U, \operatorname{trn} A-U G C, \\
\text { petB, petD, atpF, } \\
\text { rpl16, rpoC1, rps16 }\end{array}$ \\
\hline Genes with two introns & $\operatorname{rps} 12, c l p P, y c f 3$ & $\operatorname{rps} 12, \mathrm{clpP}, y c f 3$ \\
\hline $\begin{array}{l}\text { GenBank accession } \\
\text { number }\end{array}$ & KY908400 & KY908401 \\
\hline
\end{tabular}


Structure and gene content of the Circaeaster and Kingdonia plastomes

The plastome size of Circaeaster agrestis is $151,033 \mathrm{bp}$ and that of Kingdonia uniflora is 147,378 bp (Fig. 1). Both plastomes possess the typical quadripartite structure of angiosperms, although both also contain several remarkable structural rearrangements. Most notably, a large $\sim 49 \mathrm{~kb}$ inversion in the LSC region, including all genes from trnQ-UUG to $r b c L / a c c D$ ( $a c c D$ is absent from Circaeaster) is present in both plastomes (Figs. 1, 2). In addition, both plastomes also share a much smaller inversion $(\sim 3.5 \mathrm{~kb})$ involving all four genes from $a t p B$ to trnV-UAC (Figs. 1, 2). Circaeaster also possesses a number of other unique structural changes, including a $\sim 3.5 \mathrm{~kb}$ inversion involving all four genes from psaI to petA (Figs. 1, 2) and a highly unusual IR structure. Specifically, the following changes have occurred within the IR of Circaeaster: (1) $n d h B, r p s 7$, and the 3 ' end of rps12 have shifted to a position between trnN-GUU and $y c f 1$ (compared to their typical positions between $\operatorname{trnL-CAA}$ and $\operatorname{trn} V-G A C$ in nearly all other angiosperms); (2) rpl32 and trnL-UAG are within the IR (rather than in the SSC region as in nearly all other angiosperms), and (3) $y c f 1$ is almost entirely outside the IR (rather than having $\sim 1000 \mathrm{bp}$ of $y c f 1$ within the IR, as is more typical of angiosperms). Within Kingdonia, the IR/SSC boundary has shifted to include all of $y c f 1, r p s 15, \Psi n d h H$, and $\Psi n d h A$. In both plastomes, there are unusual arrangements of rpl32 and $\operatorname{trnL}-U A G$, which in almost all other angiosperms are found adjacent to each other on the same strand within the SSC. The endpoints of these inversions were confirmed in both plastomes via PCR and Sanger sequencing using custom-designed primers (Additional files 1 and 2).

Overall, Circaeaster and Kingdonia were found to possess the typical gene and intron complement of angiosperms, with a few notable exceptions (Table 1). Both plastomes contain 30 tRNA genes and four rRNA genes, as is typical in angiosperms. The plastome of Circaeaster agrestis has 77 protein-coding genes and one pseudogene ( $\Psi$ infA, which is truncated to a length of $36 \mathrm{bp}$ ); $a c c D$ is absent. The plastome of Kingdonia uniflora only has 70 protein-coding genes due to the loss or pseudogenization of nearly all $n d h$ genes: four genes $(n d h C$, $n d h F, n d h I$ and $n d h G)$ were absent and five ( $\Psi n d h A$, $\Psi n d h B, \Psi n d h D, \Psi n d h H$ and $\Psi n d h K)$ were identified as pseudogenes. More specifically, the second exon is absent from $\Psi n d h A$ and $\Psi n d h B, \Psi n d h D$ is severely truncated to 18 bp (vs. 1503 bp in Circaeaster), $\Psi n d h H$ is truncated to $618 \mathrm{bp}$ (vs. $1182 \mathrm{bp}$ in Circaeaster) in length, and $\Psi n d h K$ is only 237 bp (vs. 669 bp in Circaeaster) in length. The Ks values of these pseudogenes were calculated between Circaeaster and Kingdonia (Additional file 3). A total of 32 and 14 repeats $\geq 30 \mathrm{bp}$ in length were found in the plastome of Circaeaster and

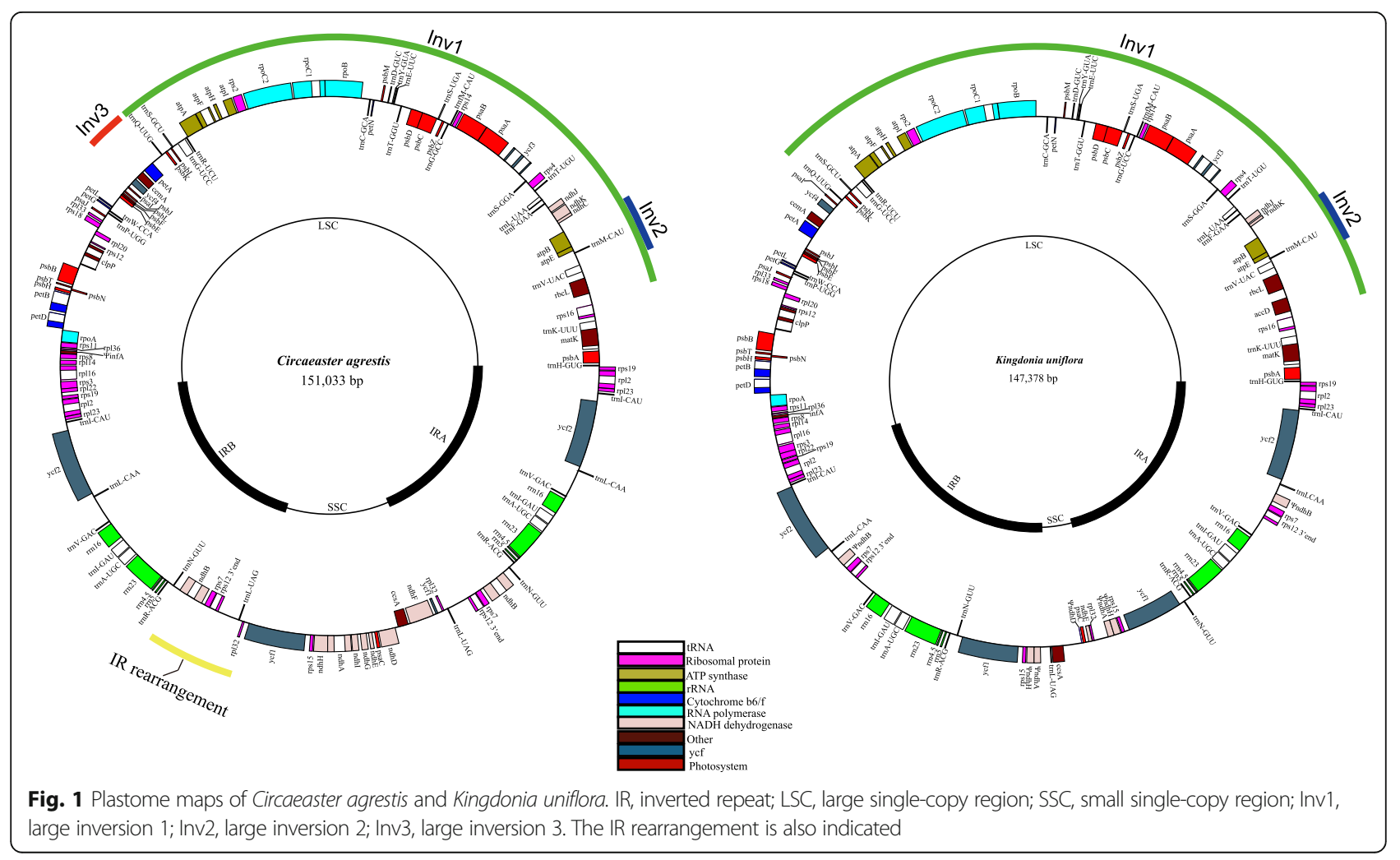




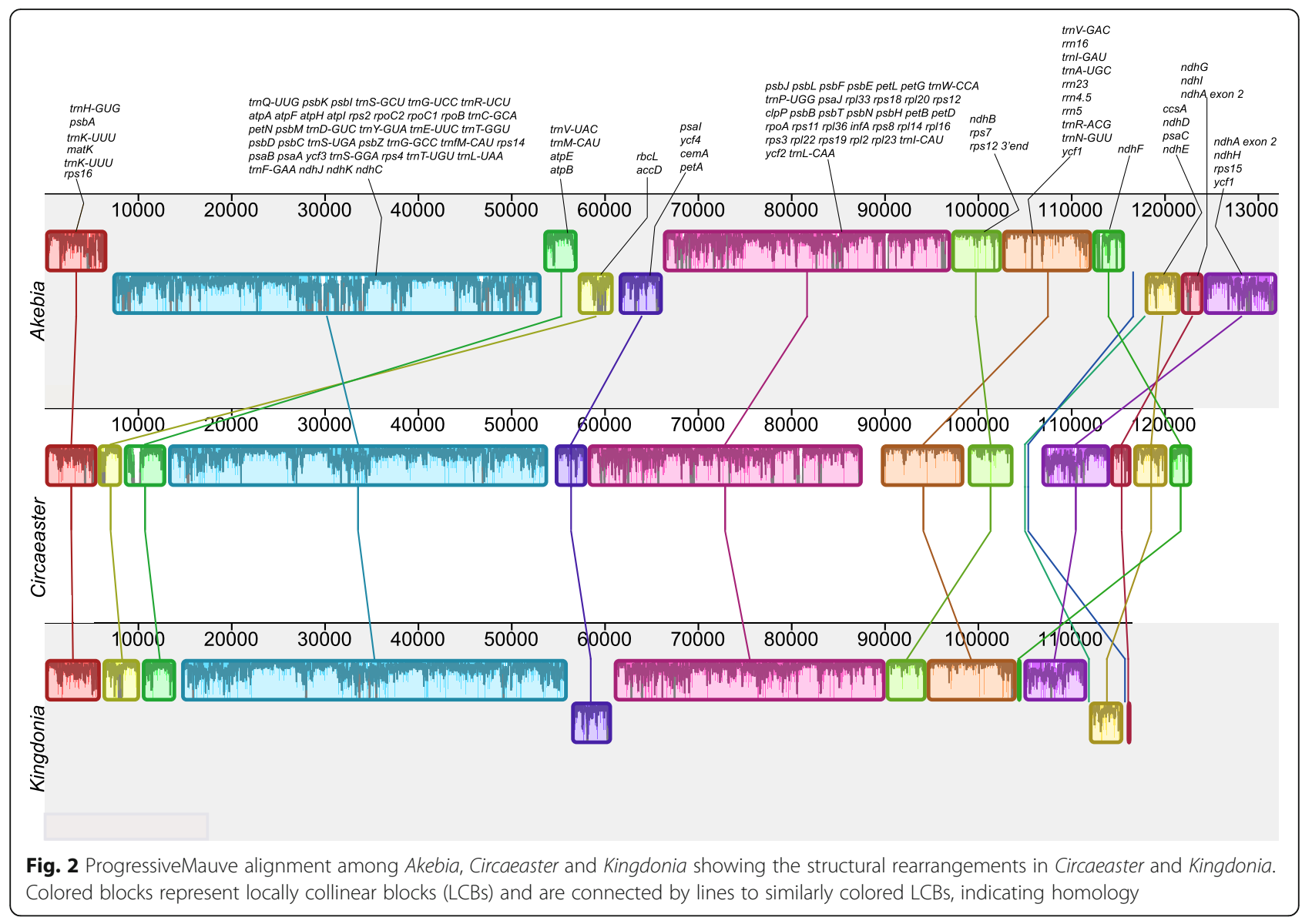

Kingdonia, respectively (Additional files 4 and 5). For comparison, the number of repeats $\geq 30$ bp in seven other Ranunculales species are as follows: (1) 17 in Akebia trifoliata (Thunb.) Koidz.; (2) 24 in Epimedium sagittatum (Sieb. \& Zucc.) Maxim.; (3) 17 in Euptelea pleiosperma Hook.f. \& Thomson; (4) 29 in Mahonia bealei (Fortune) Pynaert; (5) nine in Nandina domestica Thunb.; (6) nine in Papaver somniferum L.; and (7) eight in Stephania japonica (Thunb.) Miers (Additional file 6).

\section{Phylogenetic analyses}

The final 79-gene, 99-taxon alignment used for ML analyses was $62,238 \mathrm{bp}$ in length after character exclusion. The best partitioning scheme identified under the Bayesian information criteria (BIC) using relaxed clustering analysis in PartitionFinder ( $\ln L=-1,173,388.00241$; BIC 2353123.26941) contained 35 partitions. The tree with the highest ML score (ln $L=-1,178,285.119460$ ) produced by the 35-partition ML analysis (Fig. 3) shared an identical topology with the best tree from unpartitioned analysis ( $\ln L=-1,200,753.541175)$ (Additional file 7), except for the relationships among Trochodendrales, Buxales and Gunneridae. The 35partition analysis supported the sister relationship between Buxales and Gunneridae, but the support value was low (52\%); while the unpartitioned analysis strongly supported the sister relationship between Trochodendrales and Gunneridae. Within Ranunculales, Eupteleaceae was found to be the earliest-diverging lineage, and Papaveraceae was sister to the clade comprised of Berberidaceae, Ranunculaceae, Menispermaceae, Lardizabalaceae and Circaeasteraceae. Lardizabalaceae and Circaeasteraceae formed a strongly supported clade that was sister to the clade of Berberidaceae, Ranunculaceae and Menispermaceae.

\section{Discussion}

\section{Plastome structure and gene content}

The unusual structural rearrangements and gene losses (especially the loss of the $n d h$ genes) detected in the two Circaeasteraceae plastomes represent the first reported among early-diverging eudicot plastomes, and hence shed important insight into the evolution of early eudicot plastomes. The fact that two of the observed inversions (the $\sim 49 \mathrm{~kb}$ and $\sim 3.5 \mathrm{~kb}$ inversions) are shared by Circaeaster and Kingdonia suggests that they predate the evolutionary split between these two genera. Although uncommon, relatively large inversions have 


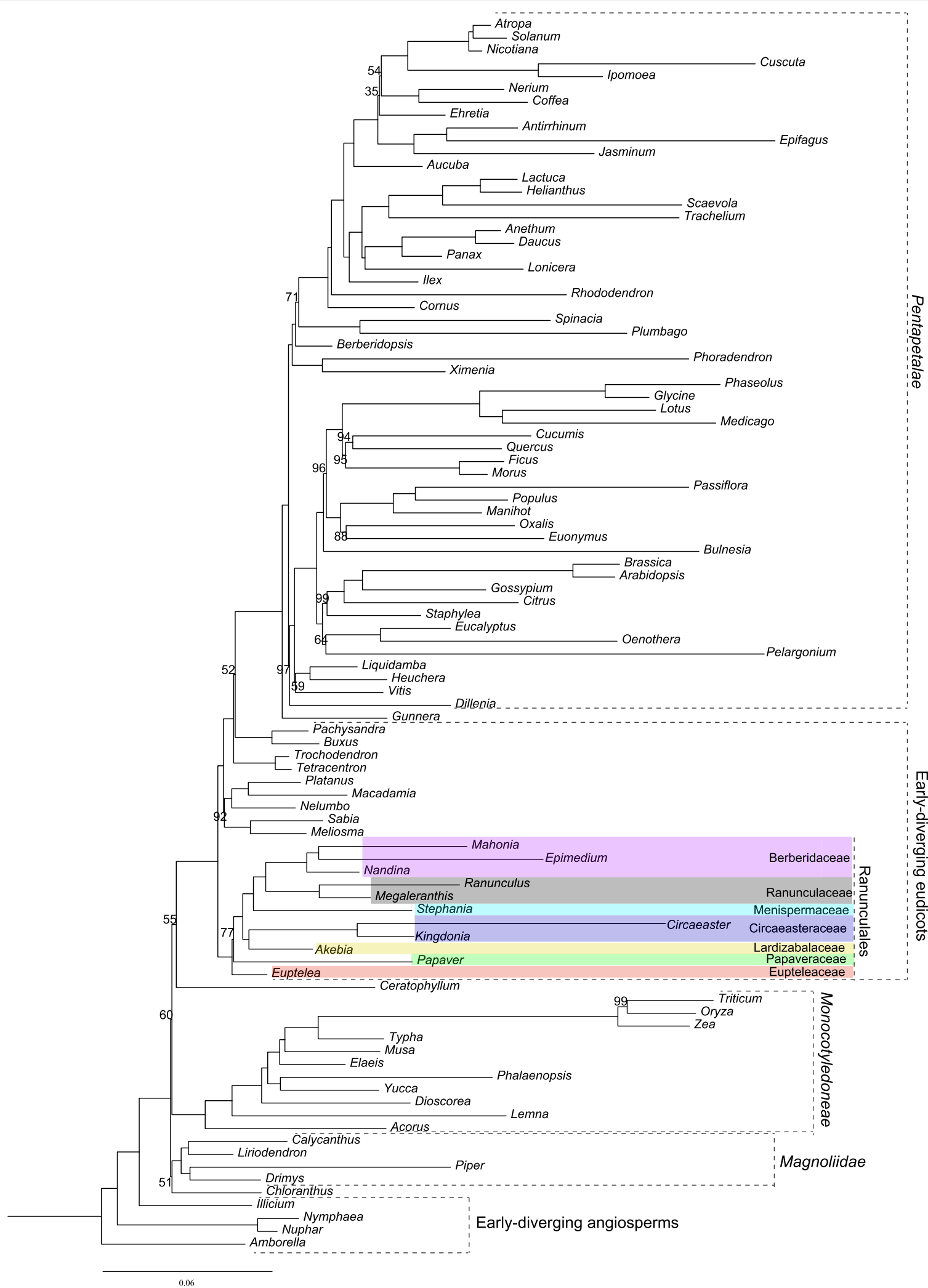

Fig. 3 Phylogram of the best tree determined by RAxML for the 79-gene, 99-taxon data set using the 35-partition scheme recovered as optimal by PartitionFinder. Numbers associated with branches are ML bootstrap support values. Branches with no bootstrap values listed have 100\% bootstrap support 
been detected in a number of other angiosperm lineages and often serve as useful phylogenetic markers [50, 52-54]. Some of the best examples of relatively large inversions that are synapomorphies for clades of flowering plants include the $22.8 \mathrm{~kb}$ inversion shared by all Asteraceae except Barnadesioideae [53, 55], the $78 \mathrm{~kb}$ inversion shared by all Fabaceae subtribe Phaseolinae [56], and the $36 \mathrm{~kb}$ inversion present in all core genistoid legumes [50, 57]. Highly rearranged plastome structures also characterize a number of other angiosperm lineages, such as Campanulaceae, Geraniaceae, and the IR-lacking clade of Fabaceae, and these are associated with greatly elevated rates of molecular evolution and large numbers of short repeats [58]. In some cases the endpoints of large plastome inversions have been found to be associated with short inverted repeats (sIRs), although we did not detect sIRs in association with the inversion endpoints in Circaeaster or Kingdonia.

The IR regions of Circaeaster and Kingdonia are also structurally unique among angiosperms, with several rearrangements. The most unusual of these involves the transposition of the $n d h B, \operatorname{rps} 7$ and $3^{\prime}$ end of the rps12 gene to a point near the junction of the $\mathrm{IR}_{\mathrm{B}}$ and the SSC region (Fig. 1). These three genes form a transcriptional operon [59] and this operon is not disrupted in Circaeaster, nor does its transposition interrupt adjacent operons. The IR/SSC endpoints themselves are also rearranged in Circaeaster, with rpl32 and trnL-UAG within the IR and non-adjacent to $n d h F$, unlike almost all other angiosperms [54]. The IR boundaries of Kingdonia are also unusual for their expansion to include several genes that are normally in the SSC (e.g. $y c f 1, r p s 15)$, resulting in a much smaller and rearranged SSC (which is also influenced by the loss of $n d h$ genes; see below). The exact sequence of rearrangements that could account for the unusual IR arrangements of Circaeasteraceae is clearly complicated and hence difficult to reconstruct. IR expansion and contraction is wellknown in a number of other angiosperm lineages (e.g. [45]), including within early-diverging eudicots, which have been found to possess a number of expansions and contractions [23]. Given the expansions and rearrangements observed in Circaeaster and Kingdonia, neither fit into any of the six IR types for early-diverging eudicots delineated in Sun et al. [23], and thus we designate two new earlydiverging eudicot IR types for Circaeaster (type G) and Kingdonia (type H) (Fig. 1).

Usually, gene content is highly conserved among photosynthetic angiosperm plastomes [50, 60], but in Circaeasteraceae, a number of genes have been lost or pseudogenized, each of which has been found to be lost repeatedly across angiosperms. For example, the loss of $a c c D$ in Circaeaster is mirrored in a number of other lineages where $a c c D$ is pseudogenized or absent, e.g., grasses [61], Lobeliaceae [62], Campanulaceae [52, 63, 64], Acorus [65], Oleaceae [66], Pelargonium [67], and Lolium perenne [68]. Likewise, infA is also known to be a pseudogene in numerous other angiosperms, including two Ranunculales (Ranunculus macranthus and Epimedium sagittatum) [23], tobacco [69], and numerous rosids [70]. Whether $a c c D$ or infA have been transferred to the nucleus in Circaeaster is unknown.

The loss or pseudogenization of nearly all $n d h$ genes from Kingdonia has also been observed in a number of other land plants. The $n d h$ genes encode subunits of the plastid NDH (NADH dehydrogenase-like) complex, which permits cyclic electron flow associated with Photosystem I and hence facilitates chlororespiration $[71,72]$. Although the NDH complex is widely retained across land plants, it has been found to be dispensable under optimal growth conditions and the plastid $n d h$ genes have been lost in a number of autotrophic and heterotrophic lineages [72, 73]. For example, the plastid $n d h$ loci have been lost or pseudogenized en masse from parasitic plants such as Orobanchaceae and Cuscuta (Convolvulaceae) [74-76], from mycoheterotrophs including several orchids [77] and Petrosavia (Petrosaviaceae) [78], and from autotrophs including Gnetales, conifers, Najas (Hydrocharitaceae), Carnegiea (Cactaceae), and Erodium (Geraniaceae) [79-84]. It is not clear whether the $n d h$ genes in Kingdonia have been transferred to the nucleus or whether their loss represents the complete loss of the NDH complex, but in any case Kingdonia is the only known early-diverging eudicot that has experienced $n d h$ pseudogenization and loss.

Moreover, the loss of the ndh genes in Kingdonia accounts for the smaller overall size of the Kingdonia plastome and may have also played an indirect role in the expansion of the IR of Kingdonia. The complete loss of $n d h F$, which normally occupies a position immediately adjacent to the $\mathrm{IR}_{\mathrm{B}} / \mathrm{SSC}$ boundary, may have led to instability of the IR/SSC boundaries, leading to rearrangements of the SSC and IR. This hypothesis is supported by other recent studies in orchids [77] and Najas flexilis [82] where $n d h F$ loss is associated with shifts in the IR/ SSC boundary.

\section{Phylogeny of Ranunculales}

The circumscription of Ranunculales was long controversial (e.g. $[3,4,9,10,85,86])$, but molecular phylogenetics has clarified the delimitation of Ranunculales to Berberidaceae, Circaeasteraceae, Eupteleaceae, Lardizabalaceae, Menispermaceae, Papaveraceae, and Ranunculaceae $[1,5,6,26,29$, $31,32,36,38]$. While the expansion of Circaeasteraceae to include Kingdonia is accepted by a majority of taxonomists [1], the rank and position of Kingdonia have long been in dispute [38]. The complete plastome sequence data strongly support the sister relationship between Kingdonia and Circaeaster, in concordance with previous molecular results [25, 26, 31, 32, 36, 38, 87]. 
The two inversions and the rare, open dichotomous leaf venation shared by these taxa are good synapomorphies that additionally support the placement of Circaeaster and Kingdonia in one family.

\section{Conclusions}

The plastomes of Circaeaster agrestis and Kingdonia uniflora provide the first reference genome sequences for Circaeasteraceae, which will enrich the sequence resources of plastomes in early-diverging eudicots. The unusual rearrangements including large inversions and unusual IR structure detected in the Circaeasteraceae plastomes will help us better characterize plastome structural evolution in early-diverging eudicots. Phylogenetic analyses of the 79-gene, 99-taxon data set confirmed the position of Circaeasteraceae in Ranunculales, with maximum support as sister to Lardizabalaceae. The two Circaeasteraceae plastomes will also be of benefit for further phylogenomic analyses within earlydiverging eudicots.

\section{Methods}

Taxon sampling, chloroplast DNA isolation, high-throughput sequencing

Fresh leaves of Circaeaster agrestis were collected from Shennongiia, Hubei Province, China, in 2015, and from Kingdonia uniflora in Meixian, Shanxi Province, China, in 2016. Voucher specimens (Circaeaster agrestis: Y.X. Sun 1510; Kingdonia uniflora: Y.X. Sun 1606) were deposited at the Herbarium of Wuhan Botanical Garden, Chinese Academy of Sciences (HIB). For both species, high-quality chloroplast DNA was obtained following the plastid DNA extraction method of Shi et al. [88]. The sequencing libraries were constructed and quantified following the methods introduced by Sun et al. [23]. For both plastomes, a 500-bp DNA TruSeq Illumina (Illumina Inc., San Diego, CA, USA) sequencing library was constructed using 2.5-5.0 ng sonicated chloroplast DNA as input. Libraries were quantified using an Agilent 2100 Bioanalyzer (Agilent Technologies, Santa Clara, CA, USA) and by real-time quantitative PCR. Libraries were then multiplexed, and $2 \times 125$ bp sequencing was performed on an Illumina HiSeq 2000 platform at the Beijing Genomics Institute.

\section{Plastome assembly, annotation, and structural analyses}

Following Sun et al. [23], duplicate reads, adaptercontaminated reads, and reads with more than five Ns were filtered out. Remaining, high-quality reads were assembled into contigs with a minimum length of $1000 \mathrm{bp}$ using CLC Genomics Workbench with default parameters, except for a word size value of 60 .
Plastomes were annotated using DOGMA [89] and through comparison with the sequences of published early-diverging eudicot plastomes. Physical maps were drawn using GenomeVx [90], followed by subsequent manual editing with Adobe Illustrator CS5. Boundaries for tRNAs were identified with tRNAscan-SE 1.21 [91] and confirmed by comparison with available earlydiverging eudicot plastome sequences. The finished genomes were deposited in GenBank (Table 1).

To investigate plastome structural evolution, whole plastome alignment between Circaeasteraceae and representatives of other early-diverging eudicot families was performed with ProgressiveMauve v 2.4.0 [92], including only one copy of the IR $\left(\mathrm{IR}_{\mathrm{B}}\right)$, and locally collinear blocks (LCBs) were identified. Because the 18 reported early-diverging eudicot plastomes in Sun et al. [23] share the same gene order, and because Circaeasteraceae was resolved as sister to Akebia in present research, the Akebia plastome was used as the reference sequence for ProgressiveMauve comparisons. mVISTA [93] was employed to generate sequence identity plots. The number and location of repeat elements in the plastomes of Circaeaster and Kingdonia as well as seven other Ranunculales species (Akebia trifoliata, Epimedium sagittatum, Euptelea pleiosperma, Berberis bealei, Nandina domestica, Papaver somniferum and Stephania japonica) were determined by REPuter [94], with a minimum size of $30 \mathrm{bp}$ and a Hamming distance of 1 . Before performing the analysis, one copy of the IR was removed.

\section{Phylogenetic analyses}

All protein-coding regions were extracted from the plastomes of Circaeaster and Kingdonia. These sequences were then added manually to the 97-taxon alignment of Sun et al. [23], resulting in a data set with complete coverage of early-diverging eudicot families sensu APG IV [1]. GenBank information for all plastomes used for present phylogenetic analyses can be found in Additional file 8. Regions of ambiguous alignment and sites with more than $80 \%$ missing data were excluded from the alignment.

Maximum likelihood (ML) analyses were conducted using RAxML version 7.4.2 [95], under the general timereversible (GTR) substitution model and the $\Gamma$ model of rate heterogeneity. We conducted both unpartitioned and partitioned analyses. PartitionFinder version 1.1.1 [96] was used to select the best-fit partitioning scheme, considering all 237 possible gene-by-codon position partitions (79 genes $\times 3$ codon positions). For both ML analyses, a single set of branch lengths for all partitions was used. Ten independent ML searches were conducted and bootstrap support was estimated with 1000 bootstrap replicates. 


\section{Additional files}

Additional file 1: Sanger chromatograms of primer products C1-C11 and K1-K8. (ZIP 2226 kb)

Additional file 2: Primers designed for verifying endpoints of plastome structural rearrangements. (DOC $54 \mathrm{~kb}$ )

Additional file 3: Ks values calculation of five pseudogenes in Kingdonia. (DOC 29 kb)

Additional file 4: Repeats $\geq 30 \mathrm{bp}$ in the plastome of Circaeaster. F, forward; $P$, palindromic. (DOC $51 \mathrm{~kb}$ )

Additional file 5: Repeats $\geq 30 \mathrm{bp}$ in the plastome of Kingdonia. F, forward; P, palindromic. (DOC $42 \mathrm{~kb}$ )

Additional file 6: Repeats $\geq 30 \mathrm{bp}$ in the plastomes of seven other Ranunculales species. (DOC $30 \mathrm{~kb}$ )

Additional file 7: Phylogram of the best tree determined by RAxML for the 79-gene, 99-taxon data set with no data partitions. Numbers associated with branches are ML bootstrap support values. Branches with no bootstrap values listed have 100\% bootstrap support. (PDF 204 kb)

Additional file 8: List of taxa included in phylogenetic analyses. (DOC 67 kb)

\section{Acknowledgments}

The authors would like to thank Gen-lu Bai for helping with collecting plant materials.

\section{Funding}

This work was supported by the National Natural Science Foundation of China (31600176, 31370242 and 31370223), and NSTIPC (2013FY111200) and SPRPCAS (XDA13020500).

\section{Availability of data and materials}

All sequences used in this study are available from the National Center for Biotechnology Information (NCBI) (see Additional file 8). Additionally, two plastomes sequenced in this study have been deposited in the NCBI genome database (Accession numbers: see Methods).

\section{Authors' contributions}

YS, HW and JL conceived and designed the study. YS performed de novo assembly, genome annotation, phylogenetic and other analyses. YS and MM drafted the manuscript. YS, NL and AK performed the experiments. AM, LY and SJ collected the leaf materials. All authors read and approved the final manuscript.

\section{Ethics approval and consent to participate}

Not applicable.

\section{Consent for publication}

Not applicable.

\section{Competing interests}

The authors declare that they have no competing interests.

\section{Publisher's Note}

Springer Nature remains neutral with regard to jurisdictional claims in published maps and institutional affiliations.

\footnotetext{
Author details

'Key Laboratory of Plant Germplasm Enhancement and Specialty Agriculture, Wuhan Botanical Garden, Chinese Academy of Sciences, Wuhan, Hubei, China 2Department of Biology, Oberlin College, Oberlin, OH, USA. ${ }^{3}$ University of Chinese Academy of Sciences, Beijing, China. ${ }^{4}$ South China Botanical Garden, Chinese Academy of Sciences, Guangzhou, China. ${ }^{5}$ Hubei Key Laboratory of Shennongjia Golden Monkey Conservation Biology, Administration of Shennongjia National Park, Shennongjia, Hubei, China.
}

Received: 3 April 2017 Accepted: 24 July 2017

Published online: 09 August 2017

\section{References}

1. Angiosperm Phylogeny Group. An update of the angiosperm phylogeny group classification for the orders and families of flowering plants: APG IV. Bot J Linn Soc. 2016:181:1-20.

2. Dahlgren G. A revised system of classification of the angiosperms. Bot J Linn Soc. 1980:80:91-124.

3. Dahlgren R. General aspects of angiosperm evolution and macro-systematics. Nord J Bot. 1983:3:119-49.

4. Takhtajan A. Diversity and classification of flowering plants. New York: Columbia University Press; 1997.

5. Angiosperm Phylogeny Group. An ordinal classification for the families of flowering plants. Ann Mo Bot Gard. 1998;85:531-53.

6. Angiosperm Phylogeny Group. An update of the angiosperm phylogeny group classification for the orders and families of flowering plants: APG II. Bot J Linn Soc. 2003;141:399-436.

7. Hutchinson J. The families of flowering plants arranged according to a new system based on their probable phylogeny. Oxford: Clarendon Press; 1973.

8. Thorne RF. Classification and geography of the flowering plants. Bot Rev. 1992:58:225-348.

9. Kubitzki K, Rohwer JC, Bittrich V. The families and genera of vascular plants II. Berlin: Springer; 1973.

10. Wu ZY, Lu AM, Tang YC, Chen ZD, Li DZ. Synopsis of a new "polyphyleticpolychronic-polytopic" system of the angiosperms. Acta Phytotaxon Sin. 2002:40:289-322.

11. Crane PR, Friis EM, Pedersen KR. Paleobotanical evidence on the early radiation of magnoliid angiosperms. Plant Syst Evol [Supplement I]. 1994;8:51-72.

12. Drinnan AN, Crane PR, Hoot SB. Patterns of floral evolution in the early diversification of non-magnoliid dicotyledons (eudicots). Plant Syst Evol [Supplement 8]. 1994;8:93-122.

13. Moore MJ, Dhingra A, Soltis PS, Shaw R, Farmerie WG, Folta KM, Soltis DE. Rapid and accurate pyrosequencing of angiosperm plastid genomes. BMC Plant Biol. 2006:6:17.

14. Hansen DR, Dastidar SG, Cai ZQ, Penaflor C, Kuehl JV, Boore JL, Jansen RK. Phylogenetic and evolutionary implications of complete chloroplast genome sequences of four early-diverging angiosperms: Buxus (Buxaceae), Chloranthus (Chloranthaceae), Dioscorea (Dioscoreaceae), and Illicium (Schisandraceae). Mol Phylogenet Evol. 2007;45:547-63.

15. Raubeson LA, Peery R, Chumley TW, Dziubek C, Fourcade HM, Boore JL, Jansen RK. Comparative chloroplast genomics: analyses including new sequences from the angiosperms Nuphar advena and Ranunculus macranthus. BMC Genomics. 2007:8:174.

16. Kim YK, Park CW, Kim KJ. Complete chloroplast DNA sequence from a Korean endemic genus, Megaleranthis saniculifolia, and its evolutionary implications. Mol Cells. 2009;27:365-81

17. Ma J, Yang BX, Zhu W, Sun LL, Tian JK, Wang X. The complete chloroplast genome sequence of Mahonia bealei (Berberidaceae) reveals a significant expansion of the inverted repeat and phylogenetic relationship with other angiosperms. Gene. 2013;528:120-31.

18. Sun YX, Moore MJ, Meng AP, Soltis PS, Soltis DE, Li JQ, Wang HC. Complete plastid genome sequencing of Trochodendraceae reveals a significant expansion of the inverted repeat and suggests a Paleogene divergence between the two extant species. PLoS One. 2013;8:e60429.

19. Nock CJ, Baten A, King GJ. Complete chloroplast genome of Macadamia integrifolia confirms the position of the Gondwanan early-diverging eudicot family Proteaceae. BMC Genomics. 2014;15:S13.

20. Wu ZH, Gui ST, Quan ZW, Pan L, Wang SZ, Ke WD, Liang DQ, Ding Y. A precise chloroplast genome of Nelumbo nucifera (Nelumbonaceae) evaluated with sanger, Illumina MiSeq, and PacBio RS II sequencing platforms: insight into the plastid evolution of early-diverging eudicots. BMC Plant Biol. 2014;14:289.

21. Lim C, Kim G, Baek S, Han S, Yu H, Mun J. The complete chloroplast genome of Aconitum chiisanense Nakai (Ranunculaceae). Mitochondr DNA. 2015;28:1-2.

22. Park S, Jansen R, Park S. Complete plastome sequence of Thalictrum coreanum (Ranunculaceae) and transfer of the rp/32 gene to the nucleus in the ancestor of the subfamily Thalictroideae. BMC Plant Biol. 2015;15:40.

23. Sun YX, Moore MJ, Zhang SJ, Soltis PS, Soltis DE, Zhao TT, Meng AP, Li XD, Li JQ, Wang HC. Phylogenomic and structural analyses of 18 complete plastomes across nearly all families of early-diverging eudicots, including an angiospermwide analysis of IR gene content evolution. Mol Phylogenet Evol. 2016;96:93-101. 
24. Zhang Y, Du L, Liu A, Chen J, Wu L, Hu W, Zhang W, Kim K, Lee S, Yang T, Wang $Y$. The complete chloroplast genome sequences of five Epimedium species: lights into phylogenetic and taxonomic analyses. Front Plant Sci. 2016;7:306.

25. Hoot SB, Crane PR. Interfamilial relationships in the Ranunculidae based on molecular systematics. Plant Syst Evol (Suppl.). 1995;9:119-31.

26. Hoot SB, Magallón S, Crane PR. Phylogeny of basal eudicots based on three molecular data sets: $a t p B, r b c L$, and 185 nuclear ribosomal DNA sequences. Ann Mo Bot Gard. 1999;86:1-32.

27. Qiu YL, Dombrovska O, Lee J, Li L, Whitlock BA, Bernasconi-Quadroni F, Rest JS, Davis CC, Borsch T, Hilu KW, Renner SS, Soltis DE, Soltis PS, Zanis MJ, Cannone JJ, Gutell RR, Powell M, Savolainen V, Chatrou LW, Chase MW. Phylogenetic analysis of basal angiosperms based on nine plastid, mitochondrial, and nuclear genes. Int J Plant Sci. 2005;166:815-42.

28. Qiu YL, Li L, Hendry TA, Li R, Taylor DW, Issa MJ, Ronen AJ, Vekaria ML, White AM. Reconstructing the basal angiosperm phylogeny: evaluating information content of the mitochondrial genes. Taxon. 2006;55:837-56.

29. Savolainen V, Fay MF, Albach DC, Backlund A, van der Bank M, Cameron KM, Johnson SA, Lledó MD, Pintaud JC, Powell M, Sheanan MC, Soltis PS, Soltis DE, Weston P, Whitten WM, Wurdack KJ, Chase MW. Phylogeny of the eudicots: a nearly complete familial analysis based on $r b c L$ gene sequences. Kew Bull. 2000a;55:257-309.

30. Savolainen V, Chase MW, Hoot SB, Morton CM, Soltis DE, Bayer C, Fay MF, De Brujin A, Sullivan S, Qiu YL. Phylogenetics of flowering plants based upon a combined analysis of plastid $a t p B$ and $r b c L$ gene sequences. Syst Biol. 2000b:49:306-62.

31. Soltis DE, Soltis PS, Chase MW, Mort ME, Albach DC, Zanis M, Savolainen V, Hahn WH, Hoot SB, Fay MF, Axtell M, Swensen SM, Nixon KC, Farris JS. Angiosperm phylogeny inferred from a combined data set of $18 \mathrm{~S}$ rDNA rbcL, and atpB sequences. Bot J Linn Soc. 2000;133:381-461.

32. Soltis DE, Senters AE, Zanis MJ. Kim S, Thompson JD, Soltis PS, Ronse de Craene LP, Endress PK, Farris JS. Gunnerales are sister to other core eudicots: implications for the evolution of pentamery. Am J Bot. 2003;90:461-70.

33. Nickrent DL, Blarer A, Qiu YL, Soltis DE, Soltis PS, Zanis M. Molecular data place Hydnoraceae with Aristolochiaceae. Am J Bot. 2002;89:1809-17.

34. Hilu KW, Borsch T, Müller K, Soltis DE, Soltis PS, Savolainen V, Chase MW, Powell MP, Alice LA, Evans R, Sauquet H, Neinhuis C, Slotta TAB, Rohwer JG, Campbell CS, Chatrou LW. Angiosperm phylogeny based on matK sequence information. Am J Bot. 2003;90:1758-76.

35. Zanis MJ, Soltis PS, Qiu YL, Zimmer E, Soltis DE. Phylogenetic analyses and perianth evolution in basal angiosperms. Ann Mo Bot Gard. 2003;90:129-50.

36. Kim S, Soltis DE, Soltis PS, Zanis MJ, Suh Y. Phylogenetic relationships among early-diverging eudicots based on four genes: were the eudicots ancestrally woody? Mol Phylogenet Evol. 2004a;31:16-30.

37. Worberg A, Quandt D, Barnikse AM, Löhne C, Hilu KW, Borsch T. Towards understanding early eudicot diversification: insights from rapidly evolving and non-coding DNA. Org Divers Evol. 2007;7:55-77.

38. Wang W, Lu A, Ren Y, Endress ME, Chen Z. Phylogeny and classification of Ranunculales: evidence from four molecular loci and morphological data. Perspect Plant Ecol. 2009;11:81-110.

39. Soltis DE, Smith SA, Cellinese N, Wurdack KJ, Tank DC, Brockington SF, Refulio-Rodriguez NF, Walker JB, Moore MJ, Carlsward BS, Bell CD, Latvis M, Crawley S, Black C, Diouf D, Xi Z, Rushworth CA, Gitzendanner MA, Sytsma KJ, Qiu YL, Hilu KW, Davis CC, Sanderson MJ, Beaman RS, Olmstead RG, Judd WS, Donoghue MJ, Soltis PS. Angiosperm phylogeny: 17 genes, 640 taxa. Am J Bot. 2011;98:704-30.

40. Ruhlman TA, Jansen RK. The plastid genomes of flowering plants. Methods Mol Biol. 2014;1132:3-38.

41. Daniell H, Lin CS, Yu M, Chang WJ. Chloroplast genomes: diversity, evolution, and applications in genetic engineering. Genome Biol. 2016;17:134.

42. Palmer JD, Stein DB. Conservation of chloroplast genome structure among vascular plants. Curr Genet. 1986;10:823-33.

43. Goulding SE, Olmstead RG, Morden CW, Wolfe KH. Ebb and flow of the chloroplast inverted repeat. Mol Gen Genet. 1996;252:195-206.

44. Plunkett GM, Downie SR. Expansion and contraction of the chloroplast inverted repeat in Apiaceae subfamily Apioideae. Syst Bot. 2000;25:648-67.

45. Downie SR, Jansen RK. A comparative analysis of whole plastid genomes from the Apiales: expansion and contraction of the inverted repeat, mitochondrial to plastid transfer of DNA, and identification of highly divergent noncoding regions. Syst Bot. 2015;40:336-51.

46. Palmer JD, Herbon LA. Plant mitochondrial-DNA evolves rapidly in structure, but slowly in sequence. J Mol Evol. 1988;28:87-97.
47. Perry AS, Brennan S, Murphy DJ, Kavanagh TA, Wolfe KH. Evolutionary reorganisation of a large operon in adzuki bean chloroplast DNA caused by inverted repeat movement. DNA Res. 2002;9:157-62.

48. Magee AM, Aspinall S, Rice DW, Cusack BP, Sémon M, Perry AS, Stefanović S, Milbourne D, Barth S, Palmer JD, Gray JC, Kavanagh TA, Wolfe KH. Localized hypermutation and associated gene losses in legume chloroplast genomes. Genome Res. 2010;20:1700-10

49. Tangphatsornruang S, Sangsrakru D, Chanprasert J, Uthaipaisanwong P, Yoocha T, Jomchai N, Tragoonrung S. The chloroplast genome sequence of mungbean (Vigna radiata) determined by highthroughput pyrosequencing: structural organization and phylogenetic relationships. DNA Res. 2010;17:11-22.

50. Martin E, Rousseau-Gueutin M, Cordonnier S, Lima O, Michon-Coudouel S, Naquin D, de Carvalho JF, Malika A, Salmon A, Ainouche A. The first complete chloroplast genome of the Genistoid legume Lupinus luteus: evidence for a novel major lineage-specific rearrangement and new insights regarding plastome evolution in the legume family Guillaume. Ann Bot. 2014;113:1197-210.

51. Jansen RK, Cai Z, Raubeson LA, Daniell H, Depamphilis CW, Leebens-Mack J, Müller KF, Guisinger-Bellian M, Haberle RC, Hansen AK, Chumley TW, Lee S, Peery R, JR MN, Kuehl JV, Boore JL. Analysis of 81 genes from 64 plastid genomes resolves relationships in angiosperms and identifies genome-scale evolutionary patterns. P Natl Acad Sci USA. 2007;104:19369-74.

52. Cosner ME, Raubeson LA, Jansen RK. Chloroplast DNA rearrangements in Campanulaceae: phylogenetic utility of highly rearranged genomes. BMC Evol Biol. 2004:4:27.

53. Kim KJ, Choi KS, Jansen RK. Two chloroplast DNA inversions originated simultaneously during the early evolution of the sunflower family (Asteraceae). Mol Biol Evol. 2005;22:1783-92.

54. Raubeson LA, Jansen RK. Chloroplast genomes of plants. In: Henry R, editor. Diversity and evolution of plants-genotypic variation in higher plants. Oxfordshire: CABI Publishing; 2005. p. 45-68.

55. Jansen RK, Palmer JD. A chloroplast DNA inversion marks an ancient evolutionary split in the sunflower family (Asteraceae). P Natl Acad Sci USA. 1987;84:5818-22.

56. Bruneau A, Doyle JJ, Palmer JD. A chloroplast DNA structural mutation as a subtribal character in the Phaseoleae (Leguminosae). Syst Bot. 1990;15:378-86.

57. Crisp M, Gilmore S, van Wyk B. Molecular phylogeny of the Genistoid tribes of Papilionoid legumes. London: Royal Botanic Gardens, Kew; 2000.

58. Jansen RK, Ruhlman TA. Plastid genomes of seed plants. In: Bock R, Knoop $\checkmark$, editors. Genomics of chloroplast and mitochondria. New York: Springer; 2012. p. 103-26.

59. Woodbury NW, Roberts LL, Palmer JD, Thompson WF. A transcription map of the pea chloroplast genome. Curr Genet. 1988;14:75-89.

60. Timmis JN, Ayliffe MA, Huang CY, Martin W. Endosymbiotic gene transfer: organelle genomes forge eukaryotic chromosomes. Nat Rev Genet. 2004;5: 123-35.

61. Katayama $\mathrm{H}$, Ogihara Y. Phylogenetic affinities of the grasses to other monocots as revealed by molecular analysis of chloroplast DNA. Curr Genet. 1996;29:5

62. Knox EB, Palmer JD. The chloroplast genome arrangement of lobelia thuliniana lobeliaceae: expansion of the inverted repeat in an ancestor of the campanulales. Plant Syst Evol. 1999;214:49-64.

63. Cosner ME, Jansen RK, Palmer JD, Downie SR. The highly rearranged chloroplast genome of Trachelium caeruleum (Campanulaceae): multiple inversions, inverted repeat expansion and contraction, transposition, insertions/deletions, and several repeat families. Curr Genet. 1997:31:419-29.

64. Haberle RC, Fourcade HM, Boore JL, Jansen RK. Extensive rearrangements in the chloroplast genome of Trachelium caeruleum are associated with repeats and tRNA genes. J Mol Evol. 2008;66:350-61.

65. Goremykin W, Holland B, Hirsch-Ernst Kl, Hellwig FH. Analysis of Acorus Calamus chloroplast genome and its phylogenetic implications. Mol Biol Evol. 2005;22:1813-22.

66. Lee H, Jansen RK, Chumley TW, Kim K. Gene relocations within chloroplast genomes of Jasminum and Menodora (Oleaceae) are due to multiple, overlapping inversions. Mol Biol Evol. 2007;24:1161-80.

67. Chumley TW, Palmer JD, Mower JP, Matthew Fourcade H, Calie PJ, Boore J, Jansen RK. The complete chloroplast genome sequence of Pelargonium $x$ hortorum: organization and evolution of the largest and most highly rearranged chloroplast genome of land plants. Mol Biol Evol. 2006;23:2175-90.

68. Diekmann K, Hodkinson TR, Wolfe KH, van den Bekerom R, Dix P, Barth S. Complete chloroplast genome sequence of a major allogamous forage species, perennial ryegrass (Lolium perenne L.). DNA Res. 2009;16:165-76. 
69. Shinozaki K, Ohme M, Tanaka M, Wakasugi T, Hayshida N, Matsubayashi T, Zaita N, Chunwongse J, Obokata J, Yamaguchi-Shinozaki K, Ohto C, Torazawa K, Meng BY, Sugita M, Deno H, Kamogashira T, Yamada K, Kusuda J, Takaiwa F, Kato A, Tohdoh N, Shimada H, Sugiura M. The complete nucleotide sequence of the tobacco chloroplast genome: its gene organization and expression. EMBO J. 1986;5:2043-9.

70. Millen RS, Olmstead RG, Adams KL, Palmer JD, Lao NT, Heggie L, Kavanagh TA, Hibberd JM, Gray JC, Morden CW, Calie PJ, Jermiin LS, Wolfe KH. Many parallel losses of infA from chloroplast DNA during angiosperm evolution with multiple independent transfers to the nucleus. Plant Cell. 2001;13:645-58.

71. Martin M, Sabater B. Plastid ndh genes in plant evolution. Plant Physiol Bioch. 2010;48:636-45.

72. Ruhlman TA, Chang WJ, Chen JJW, Huang YT, Chan MT, Zhang J, Liao DC, Blazier JC, Jin X, Shih MC, Jansen RK, Lin CS. NDH expression marks major transitions in plant evolution and reveals coordinate intracellular gene loss. BMC Plant Biol. 2015;15:100.

73. Burrows PA, Sazanov LA, Svab Z, Maliga P, Nixon PJ. Identification of a functional respiratory complex in chloroplasts through analysis of tobacco mutants containing disrupted plastid ndh genes. EMBO J. 1998;17:868-76.

74. Funk HT, Berg S, Krupinska K, Maier UG, Krause K. Complete DNA sequences of the plastid genomes of two parasitic flowering plant species, Cuscuta reflexa and Cuscuta gronovii. BMC Plant Biol. 2007;7:45.

75. Haberhausen G, Zetsche K. Functional loss of all ndh genes in an otherwise relatively unaltered plastid genome of the holoparasitic flowering plant Cuscuta reflexa. Plant Mol Biol. 1994;24:217-22.

76. Wolfe $\mathrm{KH}$, Morden CW, Palmer JD. Function and evolution of a minimal plastid genome from a nonphotosynthetic parasitic plant. P Natl Acad Sci USA. 1992;89:10648-52.

77. Kim HT, Kim JS, Moore MJ, Neubig KM, Williams NH, Whitten WM, Kim JH. Seven new complete plastome sequences reveal rampant independent loss of the ndh gene family across orchids and associated instability of the inverted repeat/small single-copy region boundaries. PLoS One. 2015;10:e0142215.

78. Logacheva MD, Schelkunov MI, Nuraliev MS, Samigullin TH, Penin AA. The plastid genome of mycoheterotrophic monocot Petrosavia stellaris exhibits both gene losses and multiple rearrangements. Genome Biol Evol. 2014;6: 238-46.

79. Blazier J, Guisinger MM, Jansen RK. Recent loss of plastid-encoded ndh genes within Erodium (Geraniaceae). Plant Mol Biol. 2011;76:263-72.

80. Braukmann TWA, Kuzmina M, Stefanovic S. Loss of all plastid ndh genes in Gnetales and conifers: extent and evolutionary significance for the seed plant phylogeny. Curr Genet. 2009;55:323-37.

81. McCoy SR, Kuehl JV, Boore JL, Raubeson LA. The complete plastid genome sequence of Welwitschia mirabilis: an unusually compact plastome with accelerated divergence rates. BMC Evol Biol. 2008:8:130.

82. Peredo EL, King UM, Les DH. The plastid genome of Najas flexilis: adaptation to submersed environments is accompanied by the complete loss of the NDH complex in an aquatic angiosperm. PLoS One. 2013;8:e68591.

83. Sanderson MJ, Copetti D, Búrquez A, Bustamante E, Charboneau JLM, Eguiarte LE, Kumar S, Lee HO, Lee J, McMahon M, Steele K, Wing R, Yang TJ, Zwickl D, Wojciechowski MF. Exceptional reduction of the plastid genome of saguaro cactus (Carnegiea gigantea): loss of the ndh gene suite and inverted repeat. Am J Bot. 2015;102:1115-27.

84. Wakasugi T, Tsudzuki J, Ito S, Nakashima K, Tsudzuki T, Sugiura M. Loss of all ndh genes as determined by sequencing the entire chloroplast genome of the black pine Pinus thunbergii. P Natl Acad Sci USA. 1994;91:9794-8.

85. Cronquist A. The evolution and classification of flowering plants. second ed. New York: New York Botanical Garden; 1988.

86. Thorne RF. An updated classification of the class Magnoliopsida ("Angiospermae"). Bot Rev. 2007;73:67-182.

87. Oxelman B, Lidén M. The position of Circaeaster - evidence from nuclear ribosomal DNA. Plant Syst Evol (Suppl). 1995;9:189-93.

88. Shi C, Hu N, Huang H, Gao J, Zhao Y, Gao L. An improved chloroplast DNA extraction procedure for whole plastid genome sequencing. PLoS One. 2012;7:e31468

89. Wyman SK, Jansen RK, Boore JL. Automatic annotation of organellar genomes with DOGMA. Bioinformatics. 2004;20:3252-5.

90. Conant GC, Wolfe KH. GenomeVx: simple web-based creation of editable circular chromosome maps. Bioinformatics. 2008;24:861-2.

91. Schattner P, Brooks AN, Lowe TM. The tRNAscan-SE, snoscan and snoGPS web servers for the detection of tRNAs and snoRNAs. Nucleic Acids Res. 2005;33:W686-9
92. Darling AE, Mau B, Perna NT. ProgressiveMauve: multiple genome alignment with gene gain, loss and rearrangement. PLoS One. 2010;5:e11147.

93. Frazer KA, Pachter L, Poliakov A, Rubin EM, Dubchak I. VISTA: computational tools for comparative genomics. Nucleic Acids Res. 2004;32:W273-9.

94. Kurtz S, Choudhuri JV, Ohlebusch E, Schleiermacher C, Stoye J, Giegerich R. REPuter: the manifold applications of repeat analysis on a genomic scale. Nucleic Acids Res. 2001;29:4633-42.

95. Stamatakis A. RAxML version 8: a tool for phylogenetic analysis and postanalysis of large phylogenies. Bioinformatics. 2014;30:1312-3.

96. Lanfear R, Calcott B, Ho SWW, Guindon S. PartitionFinder: combined selection of partitioning schemes and substitution models for phylogenetic analyses. Mol Biol Evol. 2012;29:1695-701.

\section{Submit your next manuscript to BioMed Central and we will help you at every step:}

- We accept pre-submission inquiries

- Our selector tool helps you to find the most relevant journal

- We provide round the clock customer support

- Convenient online submission

- Thorough peer review

- Inclusion in PubMed and all major indexing services

- Maximum visibility for your research

Submit your manuscript at www.biomedcentral.com/submit 